\title{
A diferença da educação escolar indígena na colonização portuguesa de Angola e Brasil
}

\author{
Paulo Roberto Vilarim ${ }^{1}$ (i) \\ Universidade de Coimbra, CFisUC - Centro de Física da Universidade de Coimbra \\ Décio Ruivo Martins 2 (iD \\ Universidade de Coimbra, CFisUC - Centro de Física da Universidade de Coimbra
}

Sérgio Paulo Jorge Rodrigues 3 (iD)

Universidade de Coimbra, CQC, Departamento de Química

Artigos livres | Free articles | Articulos libres

DOI do artigo: 10.22481/odeere.v6i2.9766

\section{RESUMO}

Com o presente artigo, pretende-se discorrer a cerca de alguns aspectos da educação escolar indígena em Angola e no Brasil, a busca por uma autonomia da educação escolar indígena dos povos originais e suas diferenças. Elementos importantes foram considerados na escolha destes países como a história da educação escolar indígena, país colonizador, politica mundial e revoluções. A pesquisa é desenvolvida a partir de estudos bibliográficos e faz parte de um recorte de uma pesquisa de doutorado em andamento. Os resultados mostram que independentemente do país colonizador, o modus operandi das ocupações não se diferenciaram significativamente em relação aos massacres e à imposição cultural. Questões políticas e da posição geográfica corroborarem para a degradação da educação, muito é possível capturar nas últimas décadas, uma evolução significativa, por protagonismo dos próprios povos originais que abraçaram a educação como uma forma de resistência.

Palavras chave: Educação; Colonização; Política pública; Resistência.

\section{The difference of indigenous school education in the portuguese colonization of Angola and Brazil \\ ABSTRACT}

With this article, we intend to discuss some aspects of indigenous school education in Angola and Brazil, the search for an autonomy of indigenous school education of the original peoples and their differences. Important elements were considered in the choice of these countries, such as the history of indigenous school education, colonizing country, world politics and revolutions. The research is developed from bibliographic studies and is part of a part of an ongoing doctoral research. The results show that regardless of the colonizing country, the modus operandi of the occupations did not differ significantly in relation to massacres and cultural imposition. Political issues and geographic position contribute to the degradation of education, much is possible to capture in recent decades, a significant evolution, due to the prominence of the original peoples who embraced education as a form of resistance.

Keywords: Education; Colonization; Public policy; resistance.

\section{Submetido em: 28/10/2021 | Aceito em: 24/11/2021}

\footnotetext{
1 Professor de Física do IFMS/CG. Bacharel em Física na Universidade Estadual de Maringá (UEM), Licenciado em Física na UTFPR, Mestre em Física da Matéria Condensada na UEM e Doutorando em História da Ciência e Educação Científica pela Universidade de Coimbra (UC). E-mail: paulo.vilarim@ifms.edu.br

2 Doutoramento em História e Ensino da Física pela Universidade de Coimbra. Tem diversos trabalhos publicados sobre História da Ciência e Etnociência. Pertenceu à Comissão científica do Museu da Ciência da Universidade de Coimbra. É coordenador do Curso de Doutoramento em História das Ciências e Educação Científica da Universidade de Coimbra. E-mail: decio@uc.pt

3 Doutorado em Química e professor da Universidade de Coimbra. A sua área de investigação é a química teórica e computacional e as suas aplicações em química ambiental, astroquímica e química medicinal. Tem também interesse pelo ensino e história da química, assim como pela divulgação e comunicação de ciência. E-mail: spirodrigues@gmail.com
} 


\section{0- Introdução}

Neste artigo pretende-se discorrer acerca de alguns aspectos da educação escolar indígena entre Angola e Brasil, países colonizados por Portugal, buscando mostrar aspectos diversos da colonização refletidos na educação escolar indígena dos povos originais. Pretende-se comparar os diferentes aspectos e características dos países estudados e seus desenvolvimentos na educação escolar indígena. Com isso pretendesse analisar como é inserido no contexto educacional atual e a importância de rever os aspectos históricos das colonizações para entendermos os meandros da educação escolar indígena na história dos países colonizados e como os diferentes povos lidaram e lidam com a educação. Observa-se que a pesquisa foi desenvolvida por meio de uma revisão bibliográfica e é o recorte de uma pesquisa em andamento de doutorado.

Não se pretendesse aprofundar em todos os aspectos das duas colonizações portuguesas e sim revelar indícios de como cada uma, ocorrida em Angola e no Brasil, impactou a educação escolar indígena. Elementos importantes foram considerados na escolha destes países como a diferença na condução da educação escolar indígena, ter o mesmo colonizador e na diferenciação das políticas educacionais.

Refletir acerca da educação escolar indígena em diversos contextos e países é reconstruir os fatos da educação escolar indígena num panorama global. O estudo da educação formal ou escolar (ocidentalizada) dos indígenas e como estão na atualidade se faz necessário para se compreender como atualmente os povos originais lidam com a educação. E pretende-se demonstrar que a origem étnica influenciou muito o andamento social e político nos países pesquisados, assim como na própria história da educação escolar.

Discorrer sobre a história da educação escolar diretamente para os índios nos países Angola e Brasil é ponderar de forma pragmática um modelo de educação que se idealiza como "formal". Porém, já existia uma educação formal nas diferentes tribos em todo mundo que não seguia os formatos de decoração e memorização de amplo conteúdo didático. A educação era direcionada e para características de cada indivíduo da comunidade, separada por sexo e constituição física. A transferência de conhecimento dos mais velhos para os jovens, dos homens para os meninos, de mulheres para meninas, e abrangendo a 
história, cultura e religião criou uma educação que foi transmitida em uma tradição oral de comunicação.

Iniciamos este artigo descrevendo alguns aspectos do início das colonizações dos dois países, ou seja, como no decorrer da história se deu a educação escolar indígena nos países de estudo. Em seguida, comparamos a construção da educação escolar indígena nestes países e, por fim, analisamos os aspectos que os diferencia e como estão na atualidade.

\section{0- Sobre a educação escolar indígena em Angola}

A carne mais barata do mercado é a carne negra! Trecho da Música de Elza Soares.

Antes da chegada do navegador Diogo Cão, a foz do rio Zaire em 1482, a educação nas tribos que viviam em toda a região dava-se por meio de transmissão oral. Muito dos conhecimentos tradicionais eram transmitidos por histórias, provérbios, musicas, danças e mitos. Uma cultura extremamente rica que era transmitida de geração em geração em harmonia com a natureza em com os indivíduos das sociedades em que estavam inseridos.

Tal harmonia foi quebrada pelos primeiros missionários católicos ao chegar à região em 1491. Quando os Portugueses desembarcaram no continente africano não encontraram "selvagens", e sim, sociedades organizadas em reinados e bem estruturadas. Um dos reinos que recebeu os portugueses foi o do Rei do Congo (Manicongo) Nzinga Nkuvu que se deixou batizar pelos missionários, para manter uma diplomacia comercial entre os portugueses e seu reinado. Apesar do rei Nzinga não seguir a religião católica, após sua morte, o seu filho e sucessor Nzinga Mbemba tornou o catolicismo a religião oficial do seu reinado, construindo igrejas e mudando o nome da capital para São Salvador do Congo.

Com a ascensão de Mbemba e sua conversão, criou-se dentro dos outros reinos um descontentamento e uma grande crise se instalou, provocando guerras e a dissolução dos reinados. Neste interim, os portugueses tiveram vantagens, pois com as guerras e desunião entre os reinados o comércio de escravos prosperou assim como o comércio de marfim e animais exóticos.

Entre 1563 e 1575 a educação escolar era quase inexistente, pois o comércio escravagista se sobressaía obedecendo à máxima de Paulo Dias de Novais, $1^{\circ}$ Governador e Capitão-General de Angola que afirmava: "[...] a experiência 
demonstrou que os bantu eram bárbaros selvagens que não podiam ser convertidos pelos métodos pacíficos empregados em nações asiáticas tão cultas como a japonesa e a chinesa". E o mesmo afirma que a evangelização "tinha de ser imposto pela força das armas, ainda que, uma vez que os bantu estivessem convertidos se tornassem cristãos excelentes submissos" (Boxer, 1986). Bantu é um termo africano que significa pessoas, sendo o seu singular - ntu - pessoa.

142 anos depois da chegada dos missionários, em 1624, inicia-se um colégio jesuíta em São Salvador do Congo que durou até 1641 em função da guerra entre Portugal e Holanda. A catequização tinha uma dupla funcionalidade: propagar a cultura cristã "Branca" e o desmantelamento das crenças e cultura nativa "Preta", para posteriori fissão dos grupos indígenas. Os jesuítas se espalharam por todo o país e promoviam uma educação diferenciada: para os nativos, a catequização, e, para os filhos dos colonos, uma educação formal seguindo o Ratio Studiorum (Ratio atque Institutio Studiorum Societatis lesu /Plano e Organização de Estudos da Companhia de Jesus). A ligação do cristianismo com a educação jesuítica permitiu aos missionários fundarem escolas e nelas os angolanos foram obrigados a entrarem em contato com a religião cristã (Opoku, 1991, p.536).

Portanto, a educação tinha um papel fundamental na desafricanização, produzindo assim um terreno fácil para exploração dos povos e da terra. Não era um processo fácil, pois as constantes guerras e disputas não faziam o trabalho dos missionários fácil, "a missionação do interior isolado era um esforço sobre-humano, um sacrifício abnegado e heroico, um verdadeiro desafio à morte, que quase sempre vencia nesta disputa" (Valente, 1964, p.99). Os governantes consideravam o comércio dos escravos mais importante do que a evangelização, o que levou a educação jesuíta a um tremendo fracasso na sua essência, pois ia contra o comércio escravagista. A morosidade das políticas educacionais e o desinteresse em "catequizar" mercadorias.

Em 1640, o brasileiro Salvador Correia de Sá retoma Angola dos holandeses e a rota de escravo passa ser Angola/Portugal/Brasil. Nos anos seguintes, o comércio de escravos passou a ser quase todos destinados ao Brasil com os navios carregados, "cerca de 20 mil escravos saíam de Luanda e Benguela, e desse total só 12 ou 13 mil chegavam ao Brasil" (Dilolwa, 1978, p.16). Posteriormente, o comércio passa a ser Angola/Inglaterra/Portugal/Brasil em função da dependência dos produtos manufaturados provenientes da Inglaterra no qual os 
portugueses eram condicionados.

Com a expulsão dos jesuítas no período Pombalino (1759 a 1792), a administração de Angola passa para D. Francisco Inocêncio de Souza em 1764 e não há preocupação em investir na educação por não haver relação positiva para o comercio de escravos, maior lucro da Coroa portuguesa. Não há empenho no aprimoramento da educação, uma vez que poderia ser arriscado a desestabilização do lugar do nativo de pele preta como mercadoria.

Já no período Joanino (1792 a 1845), houve algumas mudanças políticas como abertura dos portos e o processo da abolição da escravatura. Contudo, a educação escolar dos indígenas sofreu com o abandono intencional, não muito diferente dos governos anteriores. Em contrapartida, o comércio na colônia prosperava, segundo Dilolwa (1978, p.18), "em 1796, Luanda era o terceiro porto importador do Rio de Janeiro (Brasil) e Benguela era o sexto". Após 309 anos após a chegada dos missionários, em 1800 é fundada a primeira escola primária em Benguela, intimamente ligada a instrução básica de leitura e escrita em português.

Somente em 1835, o ministro Rodrigues da Fonseca cria o Conselho Superior da Instrução Pública e em 1836 ocorre à abolição da escravatura em Angola. Contudo somente em 1845 com o ministro Joaquim José Falcão ocorreu uma expansão das escolas primarias e a regulação das atividades dos professores. Em 1870 já havia uma escola a cada 40 km² e 6 escolas a cada dez mil habitantes em Angola (Silva Neto, 2005, p 1 16). A autora destaca a importância da expansão das escolas protestantes em 1878, pois a educação escolar indígena passou por uma mudança significativa na sua concepção, pois a igreja defendia a necessidade de utilizar as línguas dos nativos e introduziu temas como liberdade e democracia, apesar do caráter religioso que as escolas mantinham.

Em 1891, um decreto "obrigava" a abertura de escolas em localidades com mais de 500 habitantes, que foi totalmente ignorada. E somente em 1911 que Jaime Morais, governador geral de Angola, decreta o ensino técnico para os nativos e com o governador Massano Amorim (1918) houve uma expansão das escolas profissionalizantes para os nativos. Esta prerrogativa estava em preparar mão de obra especializada para os trabalhos manuais e domésticos.

Um pequeno avanço na educação escolar indígena foi a criação da primeira escola de preparação de professores primários indígenas em 1930, com setenta alunos matriculados. Quase cem anos depois da abolição da escravatura, 
em 1935, foi publicada a Portaria $n^{\circ} 2.456$, de 27 de março Art. $1^{\circ}$, que destinava colocar as crianças indígenas em condições de aprender a ser civilizado, por meio do conhecimento da língua portuguesa. Foi lançado ainda algumas resoluções governamentais que influenciavam o ensino escolar indígena neste período, o primeiro foi a Lei $n^{\circ} 2.025$ que regularizava o ensino profissionalizante para os indígenas, para suprir a falta de mão de obra qualificada para trabalhar nas indústrias, comércio e lavoura. A Portaria n 8.392, de 31 de maio de 1950, fixava, no seu artigo $28^{\circ}$ :

O ensino elementar é obrigatório para todos os indígenas, física e mentalmente sãos, na idade escolar, e destina-se a habilitá-los a ler, escrever e contar, a compreender os fatos mais simples da vida ambiente e a exercer as virtudes morais e cívicas, dentro dum vivo amor a Portugal. (Angola, Art. 28 de 1950, p. 27).

Houve uma expansão da educação escolar indígena por parte dos protestantes no período de Salazar (1926 a 1961), porém o próprio Salazar afirmava que "África deve servir a Europa" (Salazar, 1950). E pelas palavras do próprio Salazar que afirma:

Acreditamos que existem raças decadentes ou, se preferem, atrasadas, a quem sentimos ter o dever de conduzir para a civilização - tarefa esta de formação de seres humanos que deve ser levada a cabo de maneira humana. (Salazar, 1950, p. 343)

Resultado direto do pensamento e das atitudes de Salazar é que, em 1955, 99\% da população indígena era analfabeta, numa população maior em $75 \%$ de que 0 restante de pele Branca e apenas $6 \%$ dos nativos frequentavam as instituições de ensino (Castro, 1963).

Entre 1961 a 1974, a educação escolar indígena teve uma renovação com os Movimentos de Libertação Nacional (MPLA, FNLA e UNITA) que cuja maioria dos participantes era de analfabetos e semianalfabetos, e de etnias com línguas diferentes entre si. Isso implicava a necessidade de se implantar um sistema educacional que unisse os grupos, além de torná-los conhecedores das suas lutas e auxiliá-los na comunicação entre as regiões. Uma das atitudes para educação foi a elaboração de um manual de alfabetização nos dialetos nativos, criado por Carlos Rocha Dilolwa (Economista). Foi criado os CIR (Centros de Instrução Revolucionária) que, além da alfabetização, trabalhava a formação político- 
ideológica dos seus militantes e em 1965, por orientação do MPLA, foi criado em Kabinda o primeiro CIR.

O processo de ensino era realizado em barracas, cabanas, ao ar livre, nas copas das árvores, improvisando assentos, e o pé da árvore serviam de sustentação do quadro. Em meio à guerra, os professores tinham uma dupla funcionalidade: ensinar a ler e escrever e alimentar o espirito de integração - o estudante deveria ver no combatente um irmão mais velho, um igual, e unir-se a ele por uma causa maior, que era a libertação do seu país. Todos os professores e alunos tinham que obrigatoriamente também aprender as técnicas de guerrilha e os que sabiam mais ajudavam os que sabiam menos, criando uma unidade em prol da educação.

Além dos ensinamentos produzidos nos acampamentos, era comum a utilização de rádios para propagar a ideologia do movimento de libertação nacional e o ensino a distância. O Movimento criou um quadro orgânico que organizou as diretrizes e bases da educação, que posteriori foi o embrião da reforma educacional após a independência em 1975.

Em 1975, ocorreu a independência política de Angola e neste interim o partido MPLA que posteriori se transformaria em MPLA-PT (marxista-leninista) assumiu o poder no país. Houve a princípio uma debandada de professores do país e a educação ficou no início em segundo plano. Contudo, em 1977, com a participação dos professores cubanos e a reforma educativa, a educação toma novos rumos. O estado se propõe a assumir toda a responsabilidade pela educação, seguindo a teoria do marxismo-leninismo, tornando-a gratuita e ampla. Em 1973 havia um pouco mais de 170 mil angolanos matriculados no primário e, em 1977, passou de um milhão esse número, seguido também pelos os outros níveis educacionais (Marques, 2007).

A Lei Constitucional de 1977 no seu Art. $13^{\circ}$ diz que:

A República Popular de Angola combate energicamente o analfabetismo
e o obscurantismo e promove o desenvolvimento de uma educação ao
serviço do povo e de uma verdadeira cultura nacional, enriquecida pelas
conquistas culturais e revolucionárias dos outros povos (Angola, 1977)

Após a independência do país em 1975, houve uma cisão nos movimentos de libertação e o país entrov em guerra civil que foi intensificada em 1992, por este motivo as taxas de analfabetismo e a evasão escolar cresciam e em 1997 "mais de 
um milhão e meio de crianças estavam fora do sistema escolar" (Angola, 1997, p. 44). Com a lei de bases do sistema educacional $n^{\circ} 13 / 01$ a educação escolar indígena teve um avanço substancial, pois até 4 de abril de 2002 o país esteve em guerra civil entre MPLA (Movimento Popular de Libertação de Angola) e UNITA (União Nacional para Independência Total de Angola).

A Lei 13/01 é a reforma educativa que vigora atualmente e que trouxe uma estratégia para melhoria da educação no país. Um sistema bilíngue que respeita a individualidade das tribos e elenca os conhecimentos tradicionais na sua formação curricular. A Lei $n^{\circ} 17 / 16$ de 7 de outubro de 2016 substituiu a 13/01 mas sua essência continua a mesma e o desafio de educar para integrar está na sua constituição fundamental. O IDH é de 0,403 (muito baixo) e o analfabetismo está na taxa de 30\% (muito alto) (PNUD, 2013).

3.0- Aspectos da educação escolar indígena no Brasil.

As populações indígenas distinguem a educação indígena da educação escolar: a educação indígena é responsável pela aquisição das tradições, costumes e saberes específicos da comunidade, da etnia a qual o indivíduo pertence; já a educação escolar complementa os conhecimentos tradicionais e garante 0 acesso aos códigos escolares não indígenas. (Gonçalves e Mello, 2009).

A educação escolar indígena tem início no período colonial, é marcado por iniciativas de escolarização que tinham por objetivo a dominação e a assimilação dos povos indígenas e se estendeu até o final do século XX. A segunda tendência é a da escola atual, movimento que se iniciou nos anos 70 e se fortaleceu com a Constituição Federal de 1988 que ao reconhecer o direito dos indígenas à diferença, inaugurou um novo paradigma de educação escolar que propõe o respeito à diversidade cultural dos povos indígenas.

No dia 22 de Abril de 1500 Pedro Alvares Cabral chegava ao Brasil e trouxe com consigo uma educação missionária que perpetraria por muitos anos no país. Portanto, a educação seguia um modelo aplicado em muitas populações em todo mundo, em diferentes tempos, a transmissão oral entre gerações. Em Angola não era diferente: a educação estava pautada na transmissão oral e havia mais organização que a aplicada no Brasil antes da chegada dos portugueses, os povos angolanos tinham uma organização em reinos e sua educação era mais 
sistematizada que dos indígenas brasileiros.

Os missionários ensinavam os filhos dos colonos portugueses, crianças indígenas e crianças órfãs trazidas nas missões para contribuir com a dominação cultural a partir do convívio. A prática da catequização faz com que a ideia da educação agregada ao convívio das crianças, naturalize a imposição da cultura daquele que domina. Dessa forma, as crianças portuguesas conviveriam com as crianças indígenas, influenciando-as, pois estariam a frequentar a mesma escola onde aprenderiam a escrever, contar e falar português. Além de, o contato diário das crianças indígenas com seus familiares garantiria a influência na dominação cultural também com indígenas adultos. Em Angola não houve o interesse na educação primária a todos os nativos, houve apenas uma escolarização dos filhos dos chefes e a manutenção de algumas oligarquias. O comercio dos nativos era a maior preocupação da coroa portuguesa.

Na cidade de Salvador, quinze dias após a chegada dos jesuítas já se encontrava funcionando uma escola de ler e escrever em 1549. A ação dos missionários católicos foi a iniciativa mais contundente para educar os "selvagens" e, entre outras práticas que visavam a europeização e a cristianização da América, inaugurou-se assim a primeira escola indígena. Diferentemente o que foi aplicado em Angola que teve a sua primeira escola fundada após 309 anos. 70 anos após a chegada dos portugueses ao Brasil, a obra jesuítica já era composta por cinco escolas de instrução elementar (Porto Seguro, Ilhéus, São Vicente, Espírito Santo e São Paulo) e três Colégios (Rio de Janeiro, Pernambuco e Bahia).

Manoel de Nóbrega determinou o plano de estudo praticado nas escolas jesuítas e em 1599 as escolas jesuíticas passam a utilizar o manual educativo Ratio Studiorum escrito por Inácio de Loiola que consistia em regras que deveriam ser seguidos pelos os professores. Este manual instruía a regulamentação da rede educacional jesuítica através de uma lista de regras, que guiavam e organizavam diversas vertentes da instituição (LORENZ, 2018). Neste manual estava também como os estudantes deveriam ser premiados e castigados.

No decreto de 28 de maio de 1751, D. José I instituiu a liberdade dos índios como estratégia de estabelecer o controle da mão de obra indígena no país. Comparativamente entre os países em analise em Angola a abolição levou 345 anos e para os índios brasileiros 257 anos, após a chegada dos portugueses aos países. 
Um marco para educação escolar indígena no Brasil, foi a criação do "Diretório do Índio" criado em 3 de maio de 1757, inicialmente no Pará e Maranhão por Francisco Xavier de Mendonça Furtado e que se estendeu para todo o país. Uma das mais notáveis políticas indigenistas da história do Brasil, organizado em 95 parágrafos. O promotor desta iniciativa de modernizar o aparato estatal para lidar com os indígenas foi o Conde Oeiras, futuro Marques de Pombal que poria fim a fase jesuítica no mundo.

Este marco não foi positivo para os índios, pois na sua essência estava a proibição da comunicação em outro idioma afora do Português, a imposição de uma educação restritiva, além da obrigatoriedade da adoção de sobrenome português, da proibição da nudez, das habitações coletivas e o incentivo a mestiçagem como integração dos índios à sociedade nacional.

Os jesuítas são expulsos do Brasil em 1759 pelo o Marquês de Pombal e uma nova política educacional se instala no país. Foi imposto que somente o português deveria ser utilizado e houve um novo momento na educação. A educação passa a ser gerida pelo o estado e poucos professores ficam para ministrar as aulas, um efeito destruidor na educação brasileira. Para Alegre (2015), Pombal deu à política educacional um lugar central nas suas reformas, de modo a reforçar a dominação portuguesa nas colônias.

A queda do Marquês de Pombal tem início após a morte do rei D. João I, em 1777, quando D. Maria I o afasta do poder e a educação afunda um pouco mais. Em 1798 D. Maria I acaba com o Diretório dos índios e promove uma nova política indígena que mantinha o corpo da aculturação de Pombal e regulava especificamente o trabalho indígena. Não ouve nesta mudança nenhuma ação que tratasse da educação escolar indígena. Assim se manteve até a mudança da sede do governo de Portugal mudar para o Brasil em 1808 e D. João VI permitir a abertura de escolas primárias em todo o país.

No dia 7 de setembro de 1822, D. Pedro I (Brasil) e IV (Portugal) declama a independência do Brasil e a educação sofre mais uma mudança. Na primeira constituição de 1824 não há menção aos indígenas, porém há uma promessa de educação primária gratuita para todo o país. "A Constituição que foi outorgada em 1824, porém não faz referência aos indígenas. Foi mais conveniente aos legisladores negar sua existência" (SANTOS, 1995, p.94). Em 1845 no decreto no 426 regula o papel das missões na "educação indígena", um retrocesso ao Brasil 
colônia, que vigoraria até 1889.

Em 1908, no Congresso de Americanicista em Viena houve denuncias do massacre de índios no Brasil e o governo federal em contra partida cria em 1910 o Serviço de Proteção aos Índios (SPI) com o Decreto n 8072, de 20/07/1910 do Presidente Nilo Peçanha, vinculado ao ministério da agricultura. O SPI passa em 1934 para à "Inspetoria Especial de Fronteiras" do ministério da guerra (Decreto nº 24.700) e retorna para o ministério da agricultura em 1939 (Decreto-lei n 1736).

Em 1928, a lei 5.484 regulava a situação dos índios nascidos em território nacional, classificando-os e separando-os em categorias: nômades; arranchados ou aldeiados; pertencentes a povoações indígenas; pertencentes a centros agrícolas ou que vivem promiscuamente com civilizados (Brasil, 1928). Dava a SPI plenos poderes para mediar suas relações com o estado. Mas toda a lei não faz menção a educação ou a escola para os índios.

Um ponto marcante na mudança da educação escolar indígena no Brasil foi a divulgação do "Relatório Figueiredo" em 1968 pela Comissão de Inquérito (Portaria $n^{\circ}$ 239/67) do Ministério do Interior (M.I.) presidida por Jader Figueiredo para investigar e apurar irregularidades do SPI, documento M.I. - 44 - 204 de 1968, com 68 paginas. A Comissão percorreu mais de 16 mil quilômetros pelo interior do país, de Norte a Sul, e visitaram mais de 130 postos indígenas. Dezenas de testemunhas foram ouvidas e centenas de documentos da sede e das cinco inspetorias visitadas foram reunidos (M.I. - $44-204,1968$, p. 2)

Antes disso, os olhares do mundo e do próprio Brasil não enxergavam os índios. Nas reportagens descreviam as atrocidades e relatavam o que se passava nos rincões do Brasil e para a população indígena. Denúncias como escrita por Irénée Guimarães informando das atrocidades cometidas pelo o Major Luiz Vinhas Neves, antigo diretor do SPI, culpado por mais de "quarenta e dois crimes, dentre os quais, torturas e assassinatos em massa contra os índios confiados à sua proteção" (Le Monde, 1968). Braun denunciou que proprietários de terras e os agentes do SPI usaram, "além das armas convencionais, armas biológicas" (Medical Tribune, 1969). Lewis denunciou que "tribos foram exterminadas não apesar de todos os esforços do Serviço de Proteção ao Índio, mas com sua conivência - muitas vezes sua ardente cooperação" (Sunday Times, 1969).

No auge da ditadura militar no Brasil, é criada a FUNAI (Lei n 5.371 de 1967) para mascarrar a vergonha do SPI e dar uma nova roupagem à instituição. 
Desejara-se naquele momento instituir uma política indigenista que internacionalmente fosse aceita e com parâmetros integracionistas dos povos indígenas seguindo padrões internacionais. O ensino intercultural e bilíngue que se propagava nos meios acadêmicos como uma forma mais justa de modelo educacional para os povos indígenas foi elencado como padrão. Oliveira e Nascimento (2012) ressaltam que, por estar primeiramente preocupada com as questões desenvolvimentistas e da segurança nacional da época, a FUNAl, de fato, não significou avanço para os sujeitos que ela deveria atender.

A FUNAI se conveniou a Summer Institute of Linguistics (SIL) em 1970 para administrar a educação intercultural e bilíngue, que durou até 1991, contudo a SIL já estava em atividade no Brasil desde 1956. A SIL era fundamentalmente religiosa e já desenvolvia um trabalho na área linguística de tradução da Bíblia e na confecção de tradutores das línguas das comunidades indígenas na américa latina. Um claro retrocesso ao início da doutrinação cristã produzida pelos missionários no início da invasão em 1500, que traz consigo novamente característica de ordem religiosa protestante (Silva e Ferreira, 2001).

Em 1973 a Lei № 6.001 do Estatuto do Índio no seu Art. 49. Diz-se que a alfabetização dos índios far-se-á na língua do grupo a que pertençam, e em português, salvaguardado o uso da primeira. No Art. 50, desse Estatuto, determina: "A educação do índio será orientada para a integração na comunhão nacional mediante processo de gradativa compreensão dos problemas gerais e valores da sociedade nacional bem como do aproveitamento das suas aptidões individuais".

A ditadura teve fim em 15 de março de 1985 e em 5 de outubro de 1988 foi promulgada a Constituição Federal do Brasil. Com isso, várias mudanças no cenário da educação escolar indígena foi estabelecido. Na constituição foi dedicado um capitulo (VIII) que se intitulava "Dos Índios", que no seu Art. 231 assim afirma: "São reconhecidas aos índios suas organizações sociais, costumes, língua, crenças e tradições e o direito originário sobre as terras que tradicionalmente ocupam, competindo à União demarcá-las, proteger e fazer respeitar todos seus bens." (BRASIL,1988, p.150). Com as novas perspectivas colocadas pela Constituição Federal de 1988, estas se transformaram em novas possibilidades e constituição de um novo momento da história da educação escolar indígena (Valentini, 2009).

Destaca-se para educação escolar indígena para este período, a Lei de 
Diretrizes e Bases da Educação Nacional, LDB -9394/96, que na sua constituição reafirma os ideais indígenas para uma autonomia educacional. Em especial nos artigos 78 ("a recuperação de suas memórias históricas, a reafirmação de suas identidades étnicas, a valorização de suas línguas e ciências") e no Art. 32 ("O ensino fundamental regular será ministrado em língua portuguesa, assegurada às comunidades indígenas a utilização de suas línguas maternas e processos próprios de aprendizagem").

Em 1998 foi publicado um importante documento, o Referencial Curricular Nacional para Escolas Indígenas (RCNEI), que em 1999 o MEC reconhece a educação escolar indígena como uma modalidade diferenciada nas Diretrizes Nacionais para o Funcionamento das Escolas Indígenas. Em 2001 foi aprovado o Plano Nacional de Educação (PNE), que estabeleceu objetivos e metas pata a educação escolar indígena, criando a categoria oficial de "escola indígena" para que a especificidade do modelo de educação intercultural e bilíngue fosse assegurada. Em 2002 surgem os Referenciais para a Formação de Professores Indígenas e a Declaração Universal na Diversidade Cultural Manifestada salvaguardar a herança linguística da humanidade da UNESCO.

Segundo dados do Instituto Nacional de Estudos e Pesquisas Educacionais Anísio Teixeira (Inep), em 2010 existiam 1.508 escolas municipais (53,17\%) e 1.308 escolas indígenas estaduais (46,13\%). Em 2012 as Diretrizes Curriculares Nacionais para a Educação Escolar Indígena na Educação Básica, definidas pelo Conselho Nacional de Educação (CNE) e homologadas pelo MEC:

O direito das comunidades indígenas de participarem ativamente da elaboração e implementação de políticas públicas a elas dirigidas e de serem ouvidas por meio de consultas livres, prévias e informadas nos projetos ou medidas legais que as atinjam, direta ou indiretamente, coaduna-se com os preceitos que regulamentam o direito à educação escolar diferenciada. (MEC, 2012)

4.0- As diferenças na educação escolar indígena entre os países em análise.

Quando analisamos os diferentes aspectos da escolarização dos indígenas entre países, podemos notadamente perceber que para os nativos de Angola, não se restringia a dominação cultural ou dos recursos naturais que se fazia a dominação e sim o grande mercado estava na própria população. A partir da 
constatação de que os nativos eram mais valiosos do que a própria terra e são vistos como mercadoria a educação escolar passa a ser uma mera formalidade. Para que educar "aquilo" que será vendido ou escravizado?

Nesse contexto, outros países como no Brasil, seguiram uma diferenciação nas suas colonizações e na propagação da educação escolar indígena. No exemplo das colonizações inglesas que entre os aborígenes australianos e os indígenas Norte Americanos houve também uma diferenciação na história da educação escolar indígena. No EUA, da chegada dos ingleses em 1492 e os primeiros passos da educação escolar ocorre em 1520 com os franciscanos e em 1611 com os jesuítas e a primeira escola é fundada em 1568, contudo somente há uma autonomia indígena a partir de 1970. (Vine Deloria, 1978; Witmer, 1993). Na Austrália da chegada em 1770 até a formação das primeiras ações educacionais em 1814 com a fundação da primeira escola com crianças nativas em Parramatta, houve também segregação e separação de crianças do convívio dos pais em 1838 (Fletcher, 1989; Cazdow, 2007).

Quando comparamos o processo escolar dos indígenas entre Brasil e Angola percebe-se que o tempo entre a chegada e as primeiras iniciativas de escolarização tem um período maior. No Brasil da chegada em 1500 até as primeiras escolas cridas para inicialmente se ler e escrever em 1549 em Salvador na Bahia e em 1570, a obra jesuítica já era composta por cinco escolas de instrução elementar e autonomia escolar indígena ocorre somente na década de setenta. Quando comparado com a educação escolar em Angola que da chegada em 1482 até a criação do colégio jesuíta em 1624, da fundação da primeira escola em Benguela no ano de 1800 até o decreto 1891 da "obrigatoriedade" da criação de escolas em localidades com mais de 500 habitantes e que só se efetivou em 1950 com a portaria no 8.392 art. 28. Passando pela implementação do ensino técnico para os nativos para adquirir mão de obra para os colonizadores em 1911, a educação escolar indígena em Angola ficou a margem do comércio e exploração dos nativos.

Observe o quadro abaixo que mostra, nos marcos temporais, parte de momentos da educação escolar indígenas entre Angola e Brasil: 
Tabela 01: Marcos temporais da educação escolar indígena entre Angola e Brasil.

\begin{tabular}{|c|c|c|}
\hline \multicolumn{2}{|c|}{ Angola: Ano de Contato1482 } & Brasil: Ano de Contato 1500 \\
\hline Início & 1491 missionários católicos & 1500 missionários católicos \\
\hline $\begin{array}{l}\text { Primeiras } \\
\text { Escolas }\end{array}$ & $\begin{array}{l}1624 \text { criação do colégio jesuíta em } \\
\text { São Salvador do Congo; } \\
1800 \text { é fundada a primeira escola } \\
\text { primária em Benguela. } \\
1930 \text { criação da primeira escola de } \\
\text { preparação de professores } \\
\text { primários indígenas; } \\
1965 \text { criação do primeiro CIR }\end{array}$ & $\begin{array}{l}1549 \text { primeira escola de ler e escrever em } \\
\text { Salvador/BA; } \\
\text { 1570, cinco escolas de instrução elementar } \\
\text { Jesuíta. }\end{array}$ \\
\hline $\begin{array}{l}\text { Alguns } \\
\text { Momentos } \\
\text { importantes } \\
\text { que } \\
\text { influenciaram } \\
\text { na } \\
\text { educação } \\
\text { escolar } \\
\text { indígena }\end{array}$ & 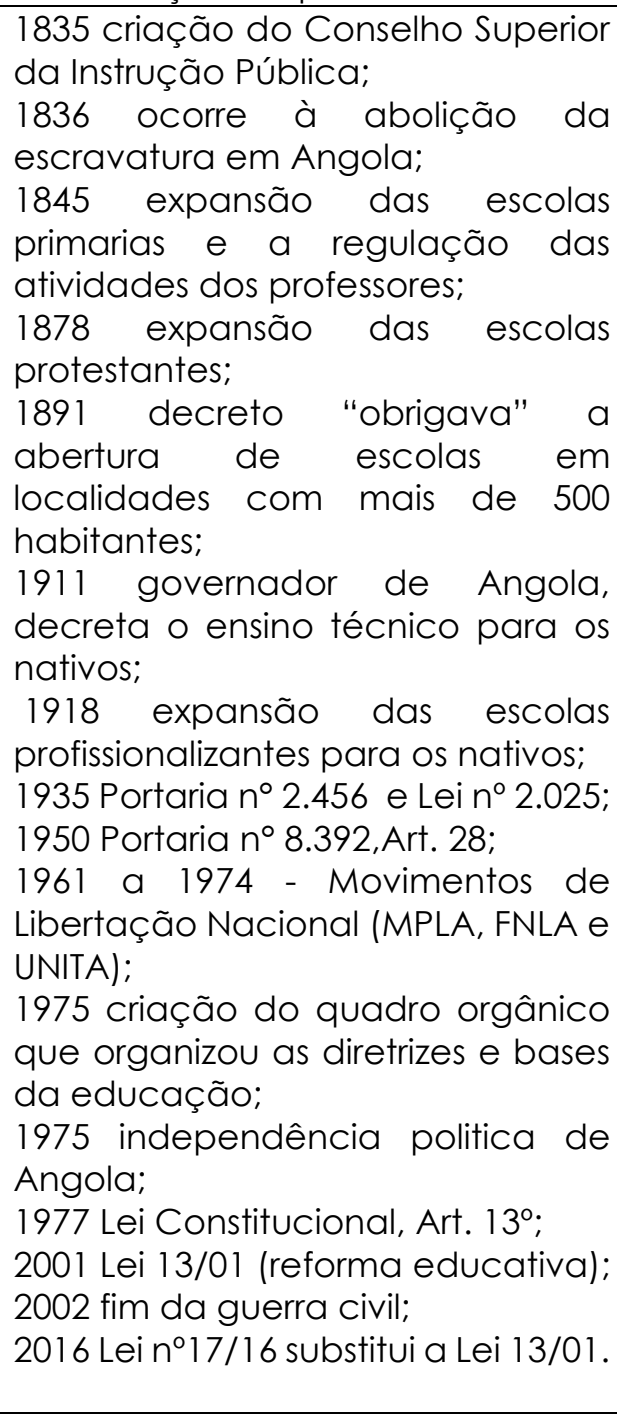 & $\begin{array}{l}\text { O3 de maio de } 1757 \text { cria-se o "Diretório do } \\
\text { Índio"; } \\
\text { Em } 1808 \text { chega a família real ao Brasil e D. } \\
\text { João VI permitir a abertura de escolas } \\
\text { primárias em todo o país; } \\
\text { Primeira constituição de 1824; } \\
1845 \text { no decreto no } 426 \text { regula o papel das } \\
\text { missões na "educação indígena"; } \\
1908 \text { no Congresso de Americanicista em } \\
\text { Viena; } \\
1910 \text { o Serviço de Proteção aos Índios (SPI) } \\
\text { com o Decreto no } 8072 \text {, de 20/07/1910; } \\
\text { Era Vargas e a constituição de 1934; } \\
\text { Portaria n'. } 75 \text { de julho de 1972 da FUNAl; } \\
1973 \text { a Lei No } 6.001 \text { do Estatuto do Índio; } \\
1988 \text { foi promulgada a Constituição Federal } \\
\text { do Brasil; } \\
1991 \text { o Decreto Federal n. 26/1991 retirada da } \\
\text { FUNAl a chancela da educação escolar } \\
\text { indígena e passa para o MEC; } \\
1992 \text { das Diretrizes para a Política Nacional de } \\
\text { Educação Escolar Indígena que tratava do } \\
\text { currículo; } \\
1996 \text { a LDB -9394/96 } \\
1998 \text { foi publicado um importante } \\
\text { documento, o Referencial Curricular Nacional } \\
\text { para Escolas Indígenas (RCNEI); } \\
2001 \text { foi aprovado O Plano Nacional de } \\
\text { Educação (PNE); } \\
\text { Decreto n. 6.861 de 2009, MEC, cria os } \\
\text { Territórios Etnoeducacionais (TEEs); } \\
2012 \text { as Diretrizes Curriculares Nacionais para } \\
\text { a Educação Escolar Indígena }\end{array}$ \\
\hline
\end{tabular}

04- Considerações finais

O preconceito racial é um diferencial da educação das populações originais e, na praticada entre Brasil e Angola, destacam-se os marcos temporais entre os dois países que servem como amostra de uma questão racial que têm suas raízes além da escola, envolvendo outros aspectos sociais, urbanísticos e políticos são aflorados nas conduções históricas destas nações e de outras.

O racismo e a diferenciação do tratamento entre as populações originais 
estão enraizados na história e no cerne dos povos nativos. A condução da educação escolar indígena, nativa ou aborígene sempre foi pautada pelo distanciamento racial entre os colonizadores e os colonizados além das políticas públicas e educacionais negligenciadas, diferentemente, do que ocorreu com as políticas voltadas para o comércio e exploração dos nativos.

Por fim, evidenciou-se neste estudo bibliográfico que tanto no Brasil quanto em Angola o modo de colonização aponta princípios comuns em relação à condução da evangelização e da implementação da educação para fins de "ler", "escrever" e "evangelizar", ainda que, em Angola, os nativos fossem subjugados ao tratamento de mercadoria mais valorizada que o próprio pau-brasil ou a expansão territorial de modo que a condução da educação escolar indígena apresentou um atraso e desenvolvimento diferenciado para os povos originais deste país. Entre os países em estudo, Brasil e Angola, os marcos temporais falam por si só implicando em políticas educacionais que continuam sendo perpetuadas até os dias atuais.

05-Referência bibliográfica

ALEGRE, M. S. P., Educação indígena colonial: ironias de um projeto. Mneme: Revista de Humanidades, Caicó, v. 15, n. 35, p. 87-110, out. 2015.

ANGOLA, Lei Constitucional, Artigo 13², p.9. Luanda. 1977

ANGOLA, MEC - Ministério da Educação e Cultura. Gabinete de Estudos Sociais. Relatório de Atividades, 1980: pp. 24-25.

BOXER. Da idealização da Frelimo à compreensão da História de Moçambique. Lisboa: Edições 70, 1986: 29-52.

BRASIL, Ministério da Justiça. Constituição Federal. Brasília: Congresso Nacional, 1988.

CASTRO, C., África Contemporânea, São Paulo, Grafica Biblos Limitada, $2^{a}$ ed. 1963.

CAZDOW, A., A NSW Aboriginal Education Timeline 1788-2007, 2007

DILOLWA, Carlos Rocha. CONTRIBUIÇÃO À HISTÓRIA ECONÓMICA DE ANGOLA. O. E. Imprensa Nacional de Angola, 1978.

Decreto Executivo no 60/01 (Estatuto Orgânico da UAN) Ministério da Educação. Imprensa Nacional de Angola, 2001. 
Decreto-Lei n ${ }^{\circ}$ 2/01 (Normas do Subsistema de Ensino Superior), Decreto-Lei n' ${ }^{\circ}$ 35/01 (Estatuto das Instituições do Ensino Superior) e o Decreto executivo n ${ }^{\circ}$ 60/01 (Estatuto Orgânico da UAN). Diário da República, 1 $^{a}$ Série, n. ${ }^{\circ} 26^{\prime \prime}$ Imprensa Nacional de Angola, (pp.73-95

Decreto-Lei no 35/01 (Estatuto das Instituições do Ensino Superior), Imprensa Nacional de Angola, 2001.

DIÁRIO DA REPÚBLICA, Lei № 4 da nacionalização do ensino, de 9 de dezembro de 1975 do Conselho da Revolução. Diário da República №. 25, 1ª Série de 1975.

DIÁRIO DA REPÚBLICA, №. 45, Resolução do Conselho de Ministros de Angola $n^{\circ}$ $6 / 83$ e o Decreto $n^{\circ} 18 / 86$.

DIÁRIO OFICIAL (Diploma Legislativo) n 128, de 17 de maio de 1930, Art. $7^{\circ}$

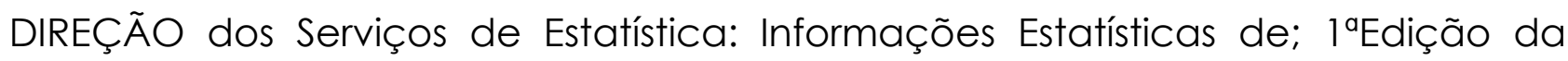
Direção dos Serviços de Estatística, Luanda-Angola, 1974. p.12. 2a Edição 1980.

DPSE - (Direção Provincial dos Serviços de Estatística), Informações Estatísticas 1972 e1973, Luanda, 1973 e 1974.

FLETCHER, JJ, Clean, Clad and Courteous: A History of Aboriginal Education in NSW, 1989.

GONÇALVES, E.; MELLO, F, Educação Indígena. Colégio Estadual Wolf Klabin, 2009. HISTÓRIA Geral de Angola. Argélia: Edições Afrontamento, 1965.

LORENZ, K., (2018), Introdução à Pedagogia Jesuíta no Brasil Colonial. Educação Humanista e o Ratio Studiorum. Cadernos de História da Educação, Uberlândia, v. 17, n. 1, p. 25-50, jan./abr.

MARQUES, I. G., (2007). "Sistema de Ensino em Angola", in Fernando Cristóvão (coord.) Dicionário Temático da Lusofonia. Lisboa: Texto Editores, Lda. $2^{a}$ Edição.

M.I., 1968, MINISTÉRIO DO INTERIOR, RELATÓRIO FIGUEIREDO, 6a Câmara da Procuradoria Geral da República, Grupos de Trabalho, GT Violação dos Povos Indígenas e Regime Militar. Disponível em: http://midia.pgr.mpf.mp.br/6ccr/relatorio-figueiredo/relatorio-figueiredo.pdf Acesso em 02 de fev de 2021

MPLA-PT Documento sobre a Educação. Edição da Imprensa Nacional Luanda, 1977

OLIVEIRA, Luiz Antonio de; NASCIMENTO, Rita Gomes do. "Roteiro para uma história da educação escolar indígena: notas sobre a relação entre política indigenista e educacional". Educ. Soc, Campinas, v. 33, n. 120, p. 765-781, 2012. Disponível em:< https://www.scielo.br/pdf/es/v33n120/07.pdf>. Acesso em abril de 2020. 
OPOKU, K., História Geral da África, São Paulo, ed. Ática, Unesco. 1991.

PNUD., A Ascensão do Sul: Progresso Humano num Mundo Diversificado. Relatório do Desenvolvimento Humano de 2013. Programa das Nações Unidas Para o Desenvolvimento. Nova lorque. (2013)

SILVA NETO, T. J. A. Tese: Contribuição a história da educação e cultura de Angola: grupos nativos, colonização e a independência. 170p. UNICAMP Campinas, SP 2005.

SALAZAR, Oliveira. O estado Novo. Lisboa: Edição Lello, 1950.

SANTOS, Silvio Coelho. Os direitos dos indígenas no Brasil. In: A temática indígena na escola. Novos subsídios para professores de $1^{\circ}$ e $2^{\circ}$ graus. Brasília, MEC/MARI/UNESCO. 1995.

SILVA, A. R.; FREITAS, M. C. S. A Institucionalização da Educação Escolar Indígena no Brasil. Revista Vozes dos Vales, Minas Gerais, 15 out. 2014.

VALENTE, Pe. J. Francisco. Seleção de provérbios e adivinhas em Umbumdu. [s. I.], [s. e.], 1964

VALENTINI, Aline de Alcântara. Histórico da Educação Escolar Indígena. Revista Pedagógica Perspectiva em Educação Caieiras, Edição 07, Ano 3. Set-Out-NovDez 2009.

VINE DELORIA, Jr. "The Indian Student Amid American Inconsistencies," em The Schooling of Native America, Thomas Thompson, ed. (Washington DC: Associação Americana de Faculdades para Professores de Educação, 1978).

WITMER, Linda F., The Indian Industrial School: Carlisle, Pennsylvania, 1879-1918, Carlisle, PA: Cumberland County Historical Society, 1993. 